Note

\title{
Inactivation Effect of Infrared Radiation Heating on Bacterial Spores Pretreated at Various Water Activities
}

\author{
DAISUKE HAMANAKA ${ }^{1 * *}$, TOSHITAKA UCHINO ${ }^{2 *}$, \\ NAOMI FURUSE ${ }^{1}$, AND SHUN-ICHIRO TANAKA ${ }^{2}$ \\ ${ }^{1}$ Graduate School of Bioresource and Bioenvironmental Sciences, and \\ ${ }^{2}$ Faculty of Agriculture, Kyushu University, 6-10-1, Hakozaki, \\ Higashi-ku, Fukuoka 812-8581, Japan
}

Received 10 May 2004/Accepted 24 September 2004

\begin{abstract}
Bacillus subtilis spores pretreated at various water activities ( $a_{w}$, from 0.005 to 0.996 ) were inactivated by infrared radiation heating (IRH) at 0.5 and $1.0 \mathrm{~kW}$ of electric power under dry conditions in an open system. The resistance of $B$. subtilis spores to IRH was greater in the range of 0.25 to $0.874 a_{w}$, and had the maximum value when $a_{w}$ was 0.796 at $0.5 \mathrm{~kW}$ and 0.688 at $1.0 \mathrm{~kW}$. Markedly lower IRH resistance of $B$. subtilis spores was observed at the lower or higher levels of $a_{w}$.
\end{abstract}

Key words : Infrared radiation heating/Water activity/Bacterial spores/Dry conditions.

Microorganisms, especially bacterial spores such as Bacillus and Clostridium, generally have a greater heat resistance in dry conditions than in wet or aqueous conditions (Shibasaki, 1998). For example, Bond et al. (1973) reported that the $D_{125^{\circ} \mathrm{C}}$ (time required to decrease the population by $90 \%$ at $125{ }^{\circ} \mathrm{C}$ ) of Bacillus sp. ATCC 27380 spores was $139 \mathrm{~h}$ under dry conditions. Fox and Eder (1969) also described that the $D_{95^{\circ} \mathrm{C}}$ of $B$. subtilis spores under dry conditions was approximately 780 times greater than that under wet conditions. Therefore, the huge thermal energy which is invested in inactivating these bacterial spores often leads to some difficult problems such as the deterioration of materials in contact with contaminant in dry heat sterilization. However, even if bacterial spores had extremely high heat resistance under dry conditions, it is considered that they would be inactivated in a short time by the inflow of a great deal of thermal energy.

Molin and Östlund (1975a and 1975b) indicated that infrared radiation heating $(\mathrm{IRH})$ can inactivate bacterial spores in a short time even under dry condi-

${ }^{*}$ Corresponding author. Tel: +81-92-642-2935, Fax : + 81-92-642-2935. tions. Also in our previous reports, we suggested that the $\mathrm{IRH}$ treatment is effective in spore inactivation under dry conditions after comparing the results from dry conditions with those from aqueous ones (Hamanaka et al., 2002 and 2003a). The higher inactivation effect of IRH results from its efficient thermal energy transfer to the substance. This is because heating media such as gas or liquid, which is indispensable to convection and heat conduction, is not necessary for $\mathrm{IRH}$. Thus, target microorganisms could be inactivated in a short time with little dissipation of thermal energy. In order to make use of these heating characteristics, we suggested that the application of $\mathrm{IRH}$ treatment to the surface disinfection of dry materials such as cereal grains (Hamanaka et al., 2003b).

The heat resistance of bacterial spores under dry conditions is affected by various environmental conditions. Especially, the surrounding water activity $\mathrm{a}_{\mathrm{w}}$ ) is an important factor (Murrell and Scott, 1957 and 1966; Peeler et al., 1977; Pfeifer and Kessler, 1994) affecting the spore heat resistance. However, there have been no reports concerning about the effect of $\mathrm{a}_{w}$ on the resistance of bacterial spores to IRH treatment. Understanding the relationships between 
the $\mathrm{IRH}$ resistance of bacterial spores and the $\mathrm{a}_{w}$ values of pretreated spores would lead to more effective efforts in spore inactivation. It is expected that the $\mathrm{IRH}$ resistance of a contaminant could be approximately predicted by monitoring the $a_{w}$ of materials. Consequently, the input energy required for sanitation in various industrial fields could be considerably decreased.

In the present study, to investigate the maximum /minimum resistance of bacterial spores to $\mathrm{IRH}$, Bacillus subtilis spores pretreated at various levels of water activity were inactivated by $\mathrm{IRH}$ treatment under dry conditions.

Bacillus subtilis subsp. subtilis NBRC 16183 obtained from NITE Biological Resource Center (NBRC; Chiba, Japan) was used. Spores were produced on a soil infusion agar plate (poly peptone (Nihon Pharmaceutical Co., Ltd., Tokyo, Japan), 10 g; yeast extract (Difco), $2.0 \mathrm{~g} ; \mathrm{MgSO}_{4} \cdot 7 \mathrm{H}_{2} \mathrm{O}, 1.0 \mathrm{~g}$; agar powder (Wako Pure Chemical Industries, Ltd., Osaka, Japan), $15 \mathrm{~g}$; soil extract, $250 \mathrm{ml}$; distilled water, 750 $\mathrm{ml}$ ) at $37{ }^{\circ} \mathrm{C}$ for $10 \mathrm{~d}$ (Berry and Brandshow, 1980; Furukawa et al., 2000). Bacteria grown on the plates were harvested by a spreader, diluted and washed twice by centrifugation at $2000 \times g$ for 10 min with sterile distilled water. This bacterial suspension was heated at $70{ }^{\circ} \mathrm{C}$ for 60 min to kill any vegetative-type cells. Finally, bacteria were stored at $5{ }^{\circ} \mathrm{C}$ until use. The spore suspension was diluted to give approximately $10^{\circ}$ colony forming units per $\mathrm{ml}$.

A modified method of Hoffman et al. (1968) was used for preparing $a_{w}$. A $2 \mathrm{ml}$ volume of this spore suspension was inoculated onto a stainless steel petri dish $(19 \times \phi 90 \mathrm{~mm})$, spread evenly, and airdried on a clean bench (MCV-710ATS, SANYO Electric Co., Ltd., Osaka, Japan) at room temperature. These stainless steel petri dishes were placed in desiccator jars containing saturated water solutions of $\mathrm{NaCl}$ and glycerol. The required $\mathrm{a}_{w}$ of those solutions were adjusted to seven levels $(0.25,0.4,0.495$, $0.624,0.688,0.796$, and 0.874$)$ at $25^{\circ} \mathrm{C}$. Two additional levels, 0.005 and 0.996 at $25{ }^{\circ} \mathrm{C}$, were prepared by using silica gel and distilled water, respectively. Thus, the equilibrium relative humidity in each desiccator jar was set at one of these nine levels. Spores inoculated on stainless steel petri dishes were placed in the desiccator jars fitted with a fan for $2 \mathrm{~d}$ to prepare the required $a_{w}$.

Figure 1 shows the experimental chamber, which was equipped with two infrared ray tubes $(330 \times \phi 12$ mm, SR-1003T, Toshiba, Japan). The electric power, peak wavelength, and peak energy of each tube were $0.5 \mathrm{~kW}, 2100 \mathrm{~nm}$, and $0.6 \mu \mathrm{W} / \mathrm{cm}^{2} / \mathrm{nm}$, respectively. The inner surface of the chamber was covered with

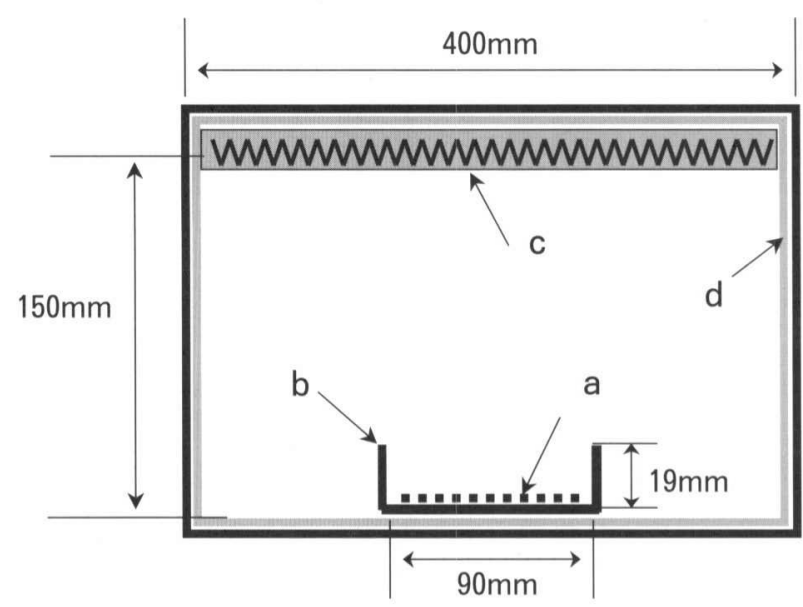

FIG. 1. Schematic diagram of the experimental chamber a, spore; b, stainless steel petri dish; c, infrared ray tube; $d$, aluminum foil.

aluminum foil to reflect infrared rays. A stainless steel petri dish inoculated with spores was set at $150 \mathrm{~mm}$ below the infrared ray tube(s). All $\mathrm{IRH}$ treatments were performed after ensuring the stabilization of radiation from the infrared ray tube (s). IRH treatments started within almost $60 \mathrm{~s}$ after the stainless steel petri dishes were taken out from the desiccator jar. The water absorption or desorption by the bacterial spores could be neglected, because the petri dish was tightly sealed with another petri dish under the condition of constant temperature until the IRH treatment was started. Thus, the $a_{w}$ of bacterial spores at the beginning of IRH treatment was regarded as the same respective $a_{w}$ value inside the desiccator jars. After IRH treatment, petri dishes were immediately cooled in a refrigerator at $4{ }^{\circ} \mathrm{C}$.

The relative humidity inside the experimental chamber was not controlled during IRH treatments. However, the relative humidity was very low, because the temperatures of air inside the chamber were approximately 130 and $200{ }^{\circ} \mathrm{C}$ at 0.5 and $1.0 \mathrm{~kW}$, respectively (data not shown). For example, even a 60 $\% \mathrm{RH}$ air at $20{ }^{\circ} \mathrm{C}$ will be reduced to below $3 \% \mathrm{RH}$ when heated to $100{ }^{\circ} \mathrm{C}$.

A $50 \mathrm{ml}$ aliquot of sterile distilled water was poured into the petri dish, and spores were removed and resuspended by ultrasonic treatment (2510J-MTH, Yamato Scientific Co., Ltd., Tokyo, Japan) for $5 \mathrm{~min}$. The numbers of initial and surviving spores were determined on a nutrient agar plate (poly peptone, $10 \mathrm{~g}$; yeast extract, $2.0 \mathrm{~g} ; \mathrm{MgSO}_{4} \cdot 7 \mathrm{H}_{2} \mathrm{O}, 1.0 \mathrm{~g}$; agar powder, $15 \mathrm{~g}$; distilled water, $1000 \mathrm{ml}$ ). These plates were incubated at $37^{\circ} \mathrm{C}$ for $24 \mathrm{~h}$, and the colonies which appeared after incubation were counted. Subsequently, the survival rate $\left(\mathrm{N} / \mathrm{N}_{0}\right)$ was calculated where $\mathrm{N}$ is the number of surviving spores and 
$N_{0}$ is the initial number of spores. All data of the surviving spores shown in the present study were the means of five experimental replications.

Figure 2 shows the changes in the survival of $B$. subtilis spores pretreated at nine levels of $a_{w}$ and exposed to IRH treatment. A shoulder phase exceeding the initial number appeared in the initial part of survival curves. The survival rate decreased exponentially with the extension of $I R H$ treatment regardless of the $a_{w}$ value. At $0.5 \mathrm{~kW}$, no rapid decrease in the spore survival by IRH treatment appeared in the range of 0.40 to $0.874 \mathrm{aw}_{\mathrm{w}}$. On the other hand, the bacterial spores pretreated at a high $\left(0.996 \mathrm{a}_{w}\right)$ or low $\left(0.005,0.25 a_{w}\right)$ level of $a_{w}$ tended to be inactivated more rapidly. Similarly at $1.0 \mathrm{~kW}$, survival rates decreased gradually in the range of 0.25 to $0.688 \mathrm{a}_{\mathrm{w}}$, and rapidly at higher $\left(0.796\right.$ to $\left.0.996 \mathrm{a}_{\mathrm{w}}\right)$ or lower $\left(0.005 a_{w}\right)$ level.

The shape of all survival curves of bacterial spores exposed to IRH treatment was an upward convex, whereas concave survival curves have often been obtained by dry heat sterilization (Fox and Pflug, 1968; Fox and Eder, 1969; Murrell and Scott, 1966). Appearance of these nonlinear parts in the survival curve often leads to a misestimation of the total treatment time required for spore inactivation, because the simple logarithmic curve has been traditionally applied to the prediction of survival. Especially when convex survival curves with a shoulder phase appeared, the predicted number of surviving spores was underestimated compared to the actual number. Consequently, some serious microbiological accidents could happen. Therefore, clarification of the relationships involving input energy, treatment time and the magnitude of the shoulder phase under various treatment conditions is very important and strongly required to perform an accurate sterilizing process using IRH treatment for practical application in various industrial fields.

Figure 3 shows the relationships between $a_{w}$ and $D$ values, which were calculated with data from the linear decreasing portion of each survival curve in Figure 2. The $D$ value at $0.005 \mathrm{a}_{w}(D=0.8 \mathrm{~min})$ was significantly smaller than that in other ranges of $a_{w}$ at $0.5 \mathrm{~kW}$. On the other hand, the $D$ value at $0.796 \mathrm{a}_{w}(\mathrm{D}$ $=8 \mathrm{~min}$ ) was significantly greater than that in other ranges of $a_{w}$ other than 0.847 . This maximum $D$ value was about 10 times greater than that of the minimum one. $D$ values in the range of 0.40 to $0.688 a_{w}$ were approximately $4.5 \mathrm{~min}$ at $0.5 \mathrm{~kW}$. At $1.0 \mathrm{~kW}$, there was no significant difference in the $D$ value between 0.005 to 0.624 and 0.796 to $0.996 \mathrm{a}_{w}$, and the $\mathrm{D}$ values in these ranges of $a_{w}$ were small (approximately 0.2 to $0.3 \mathrm{~min}$ ). Nevertheless, the $D$ value at 0.688

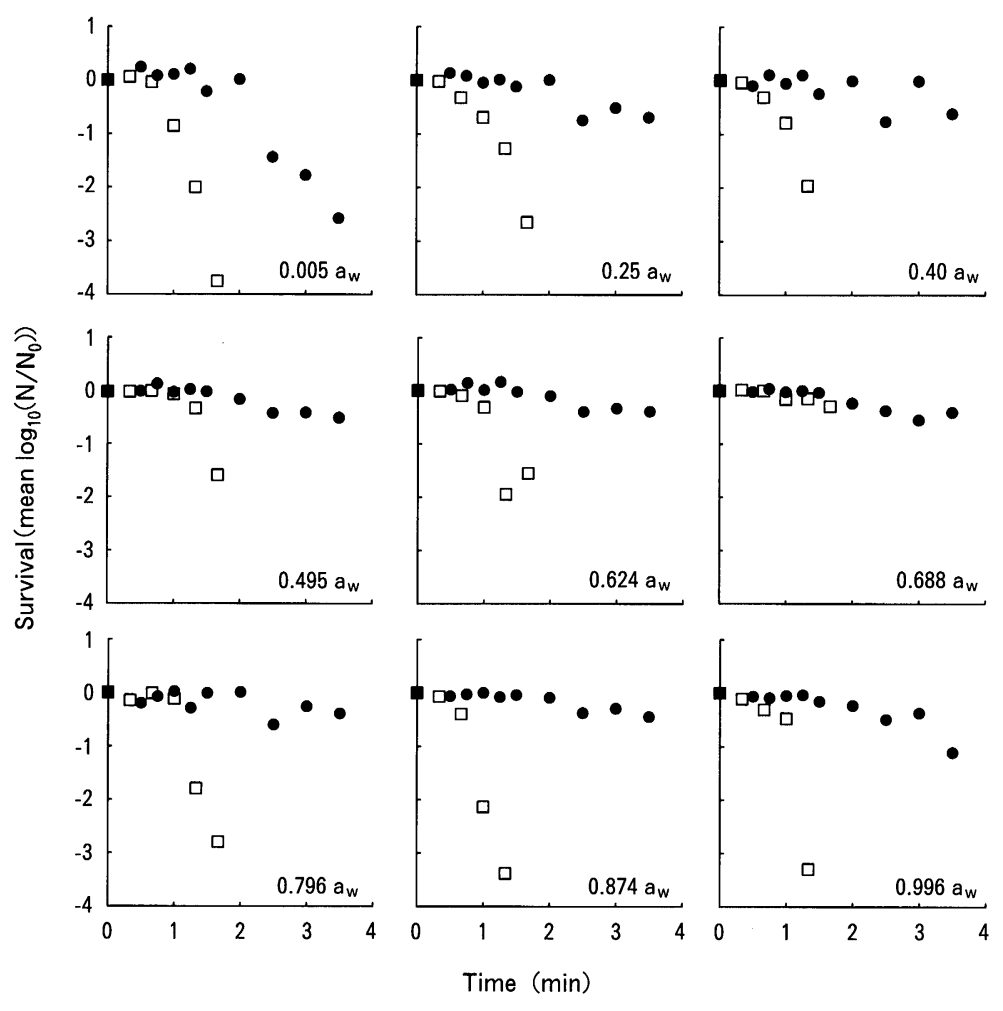

FIG. 2. Changes in the survival of $B$. subtilis spores by $I R H$ treatment pretreated with nine levels of water activity. Electric power: (O) $0.5 \mathrm{~kW},(\square) 1.0 \mathrm{~kW}$. 


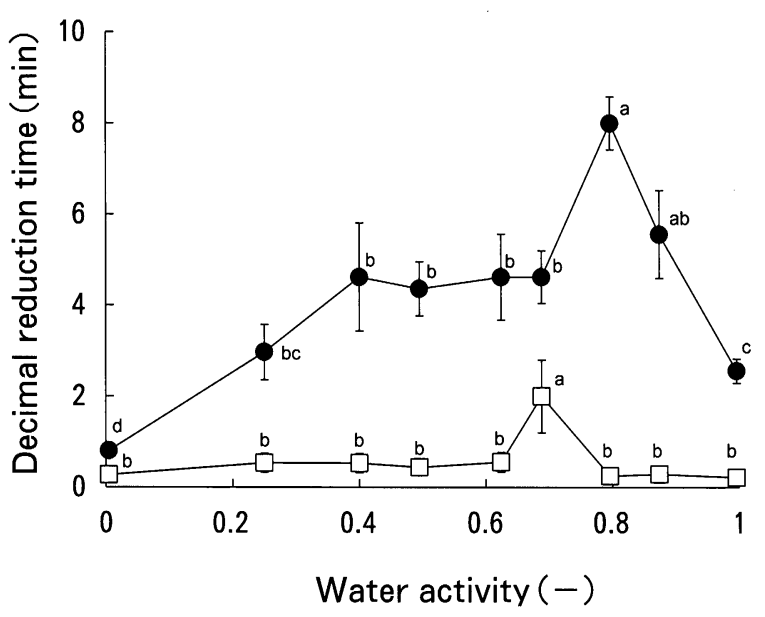

FIG. 3. Relationships between water activity and decimal reduction times of $B$. subtilis spores by $\mathrm{IRH}$ treatment. Electric power: (O) $0.5 \mathrm{~kW},(\square) 1.0 \mathrm{~kW}$. Decimal reduction times were calculated using data from the linear decreasing portion of survival curves in Fig. 2. Vertical bars indicate SE $(n=5)$. Means with different letters $(a, b, c, d)$ in same electric power are significantly different between treatments at $\mathrm{P}<0.05$ of $L S D$.

$a_{w}$ was about 2 min. Thus, there were approximately ten-fold differences in the resistance of bacterial spores to IRH treatment due to $a_{w}$.

Pfeifer and Kessler (1994) suggested that the increases in the death rate constant of bacterial spores at higher and lower ranges of $a_{w}$ were caused by the acceleration of oxidation processes and the denaturation of essential proteins (enzymes), respectively. Similarly, the decrease in the $D$ value by $\mathrm{IRH}$ treatment could result from these processes. It was also considered that the spore germination processes might be in progress during pretreatment at high $a_{w}$ conditions and the spore resistance was partly lessened, as Hyatt and Levinson (1968) reported that the activation of $B$. megaterium spores was induced by the extended water vapor treatment without heating. Additionally, here we suggested that the changes in IRH resistance were affected by heating characteristics of infrared rays. The temperature rise of a substance by infrared radiation is due to the increase of kinetic energy of the molecule resulting from the acceleration of molecular vibration when the substance absorbs infrared rays into the molecules of the surface. Therefore, the rate of temperature rise of a substance surface is considerably influenced by the correspondence between the radiation spectrum of infrared radiators and the absorption spectrum of the substance. In case that the radiation spectrum corresponded with the absorption spectrum, the vigorous molecular vibration occurs since infrared rays are easily absorbed in the molecule; consequently, the acceleration of temperature rise is obtained (Japan Society of Infrared Science and Technology, 1991). On the contrary, if there is a difference in the radiation and absorption spectrums, there are gentle rises in the temperature of the substance. In short, the increases in the $\mathrm{IRH}$ resistance of bacterial spores pretreated in the range of 0.7 to $0.8 \mathrm{a}_{\mathrm{w}}$ could be caused by the insufficient heating of bacterial spores due to the poor absorption of infrared rays by bacterial spores pretreated at this $a_{w}$ range. In order to have a more effective sterilization process, other additional sterilizing techniques are needed to be combined with $\mathrm{IRH}$ treatment when the environmental $\mathrm{a}_{\mathrm{w}}$ is around 0.7 to 0.8 .

Further detailed investigations are necessary to clarify where infrared rays are easily absorbed in the peculiar sites inside the target bacterial spores. Hoffman et al. (1968) suggested that the important factor regulating the $D$ value of bacterial spores was where and how the water molecules are bound in the cell during heating. It is considered that most of the water molecules absorbed into bacterial spores exist in the spore coat and cortex layer, since the core of bacterial spore which has high heat resistance is extremely dehydrated (Aiso, 1976). Therefore, the IRH resistance of bacterial spores might be influenced by the water existing in the spore coat and/or cortex rather than in whole spore.

\section{ACKNOWLEDGMENT}

This work was supported by a Grand in Aid for Scientific Research in 2002 from the Ministry of Education, Science, Sports and Culture of Japan.

\section{REFERENCES}

Aiso, K. (1976) Food Microbiology (in Japanese). pp101114, Ishiyaku-Shuppan, Tokyo.

Berry, M. R. Jr., and Brandshow, J. G. (1980) Heating characteristics of condensed cream of celery soup in a steriotort: Heat penetration and spore count reduction. J. Food Sci., 45, 869-879.

Bond, W. W., Favero, M. S., and Korber, M. R. (1973) Bacillus sp. ATCC27380: a spore with extreme resistance to dry heat. Appl. Microbiol., 26, 614-616.

Fox, K., and Eder, B. D. (1969) Comparison of survivor curves of Bacillus subtilis spore subjected to wet and dry heat. J. Food Sci., 34, 518-521.

Fox, K., and Pflug, I. J. (1968) Effect of temperature and gas velocity on dry-heat destruction rate of bacterial spores. Appl. Microbiol., 16, 343-348.

Furukawa, S., Nakahara, A., and Hayakawa, I. (2000) Effect of reciprocal pressurization on germination and killing of bacterial spores. Int. J. Food Sci. Technol., 35, 529532. 
Hachisuka Y., and Horikoshi K. (1976) Tolerant Type Cell (in Japanese), pp. 271-278, Iwanami Shoten, Tokyo.

Hamanaka, D., Uchino, T., Hu, W., and Yasunaga, E. (2002) Effects of infrared radiation on inactivation of Bacillus subtilis spore and Aspergillus niger spore (in Japanese). J. Jpn. Soc. Agric. Mach., 64, 69-75.

Hamanaka, D., Uchino, T., Hu, W., Tanaka, S., and Aramaki, S. (2003a) Effects of infrared radiation on inactivation and injury of $B$. subtilis and $B$. pumilus spores (in Japanese). J. Jpn. Soc. Food Sci. Technol., 50, 51-56.

Hamanaka, D., Uchino, T., Hu, W., Yasunaga, E., and Hussain, M. S. (2003b) Effects of infrared radiation on the disinfection for wheat and soybean (in Japanese). J. Jpn. Soc. Agric. Mach., 65, 64-70.

Hoffman, R.K., Gambill, V.M., and Buchanan, L.M. (1968) Effect of cell moisture on the thermal inactivation rate of bacterial spores. Appl. Microbiol., 16, 1240-1244.

Hyatt, M.T., and Levinson, H.S. (1968) Water vapor, aqueous ethyl alcohol, and heat activation of Bacillus megaterium spore germination. J. Bacteriol., 95, 20902101.

Japan Society of Infrared Science and Technology (1991) Foundation and Application of Infrared Technology (in
Japanese), pp.232-240, Ohmsha, Tokyo.

Molin, G., and Östlund, K. (1975a) Dry-heat inactivation of Bacillus subtilis var. niger spores with special reference to spore density. Can. J. Microbiol., 22, 359-363.

Molin, G., and Östlund, K. (1975b) Dry-heat inactivation of Bacillus subtilis spores by means of infra-red heating. Antonie van Leeuwenhoek 41, 329-335.

Murrell, W. G., and Scott, W. J. (1957) Heat resistance of bacterial spores at various water activities. Nature $\mathbf{1 7 9}$, 481-482.

Murrell, W. G., and Scott, W. J. (1966) The heat resistance of bacterial spores at various water activities. J. Gen. Microbiol., 43, 411-425.

Peeler, J. T., Reyes, A. L., Crawford, R. G., Wehby, A. J., and Campbell, J.E. (1977) Thermal resistance of Bacillus subtilis var. niger in a closed system. Appl. Environ. Microbiol., 33, 52-58.

Pfeifer, J., and Kessler, H. G. (1994) Effect of relative humidity of hot air on the heat resistance of Bacillus cereus spores. J. Appl. Bacteriol., 77, 121-128.

Shibasaki, I. (1998) Technology of Food Sterilization, New Edition (in Japanese). pp.14-15, Korin, Tokyo. 